\title{
ANALISIS PROSES JAWABAN SISWA TERKAIT KEMAMPUAN PEMECAHAN MASALAH PADA KELAS PEMBELAJARAN KONTEKSTUAL DAN KELAS PEMBELAJARAN BERBASIS MASALAH PADA SISWA SMP N 1 SALAPIAN
}

\author{
Kairuddin \\ Dosen Pendidikan Matematika FMIPA, Universitas Negeri Medan \\ Email : kairuddin2@yahoo.com
}

\begin{abstract}
ABSTRAK
Tujuan dari penelitian ini untuk mengetahui perbedaan kemampuan pemecahan masalah matematika siswa yang memperoleh pembelajaran kontekstual dengan siswa yang memperoleh pembelajaran berbasis masalah yang dianalisis melalui lembar jawaban siswa Penelitian ini merupakan penelitian eksperimen semu. Populasi pada penelitian ini adalah siswa kelas VII SMP Negeri 1 Salapian dengan sampel penelitian adalah Kelas VII-B yang diberikan perlakukan pembelajaran kontekstual dan kelas VII-C yang diberikan perlakuan pembelajaran berbasis masalah. Terdapat perbedaan kemamuan pemecahan masalah matematika antara siswa yang memperoleh pembelajaran kontekstual dengan siswa yang memperoleh pembelajaran berbasis masalah. Pada penelitian ini didapat bahwa proses jawaban siswa yang memperoleh pembelajaran kontekstual lebih baik dari proses jawaban siswa yang memperoleh pembelajaran berbasis masalah.
\end{abstract}

Kata kunci: Pembelajaran kontekstual, pembelajaran berbasis masalah, kemampuan pemecahan masalah

\section{ABSTRACT}

The purpose of this study is to determine the differences in mathematical problem solving abilities of students who obtain contextual learning with students who obtain problem-based learning which is analyzed through student answer sheets. This research is a quasiexperimental study. The population in this study was the seventh grade students of SMP Negeri 1 Salapian with a sample of the study was Class VII-B which was given the treatment of contextual learning and class VII-C given the treatment of problem-based learning. There are differences in the ability to solve mathematical problems between students who get contextual learning with students who get problem-based learning. In this study it was found that the answer process of students who get contextual learning is better than the answer process of students who get problem-based learning.

Keywords: Contextual Learning, Problem Based Learning,Problem solving skill

\section{PENDAHULUAN}

Matematika merupakan ilmu pengetahuan yang dipelajari hampir diseluruh negara di dunia. Banyak negara menjadikan matematika sebagai mata pelajaran penting di sekolah, sebagai bukti adanya penelitian langsung terhadap perkembangan matematika sekolah di dunia. Berdasarkan hasil laporan Programe for International Student Assessment (PISA) pada tahun 2012 (http://www.PISA/2012/.../.com) dari 65 negara, Indonesia berada pada posisi kedua

Kairuddin. Analisis Proses Jawaban Siswa Terkait Kemampuan Pemecahan Masalah Pada Kelas Pembelajaran Kontekstual dan Kelas Pembelajaran Berbasis Masalah Pada Siswa SMP Negeri 1 Salapian. Jurnal Inspiratif. Vol. 4, No. 1 April 2018. 
terendah, yaitu berada di bawah Qatar dan di atas Peru yang menjadi urutan terakhir dengan rata-rata skor 375 untuk matematika. Hal yang tidak jauh berbeda juga tertulis pada hasil laporan Trends International Mathematics and Science Study

(TIMSS)

(http://www.TIMSS/2011/.../.com) pada tahun 2011 yang menuliskan dari 42 negara yang terlibat, Indonesia berada pada urutan kelima terendah, yaitu berada di bawah Saudi Arabia dan di atas Syirian Arab Republik pada Mathematics Achievement tingkat kelas VIII, dengan rata-rata skor 386. Skor tersebut berada jauh dari TIMSS Scale Centerpoint yaitu 500.

Dari pemaparan di atas, dapat kita tarik kesimpulan bahwasanya kemampuan matematika siswa di Indonesia masih jauh dari standar Internasional. Padahal, matematika menjadi salah satu bagian dari kurikulum sekolah yang memegang peranan sangat penting dalam pendidikan di Indonesai.

Dari wawancara dengan beberapa orang siswa SMP yang kurang menyukai pelajaran matematika, mereka menganggap matematika merupakan pelajaran yang membosankan dan sulit. Mereka beranggapan tidak adanya hal yang dapat menarik keinginan mereka untuk mempelajari matematika. Matematika hanya menjadi mata pelajaran yang biasabiasa saja, tidak bermakna dan tidak berpengaruh pada kehidupan mereka. Tentu saja ini akan berpengaruh pada kemampuan pemecahan masalah siswa dimana hal ini menjadi salah satu tujuan pembelajaran matematika itu sendiri. Dengan kurangnya motivasi belajar matematika akan menimbulkan rendahnya kemampuan pemecahan masalah yang dimiliki siswa.

Kemampuan pemecahan masalah sangatlah penting dimiliki siswa, tidak hanya dalam pembelajaran matematika saja, melainkan dalam kehidupan sehari-hari. Sesuai dengan Permendiknas no. 22 tahun 2006, pendekatan pemecahan masalah merupakan fokus dalam pembelajaran matematika yang mencakup masalah tertutup dengan solusi tunggal, masalah terbuka dengan solusi tidak tunggal, dan masalah dengan berbagai cara penyelesaian. Oleh karena itu, maka perlu adanya upaya guru untuk dapat meningkatkan kemampuan pemecahan masalah yang dimiliki siswa.

Dari hasil observasi penulis terhadap 35 siswa kelas VII SMP Negeri 1 Salapian yang diberikan soal tes kemampuan pemecahan masalah pada materi prasyarat Persamaan Linier Satu Variabel, terlihat bahwa kurangnya kemampuan yang dimiliki siswa, seperti pada proses jawaban siswa dalam menyelasaikan permasalahan sebagai berikut:

Rido memiliki kelereng sebanyak $\frac{1}{3}$ dari kelereng Rudi. Reno memiliki kelereng sebanyak $\frac{3}{4}$ dari kelereng Rudi. Jika kelereng Rudi sebanyak 120 butir, berapakah jumlah kelereng mereka bertiga?

Hasil jawaban siswa dapat dilihat pada gambar berikut:

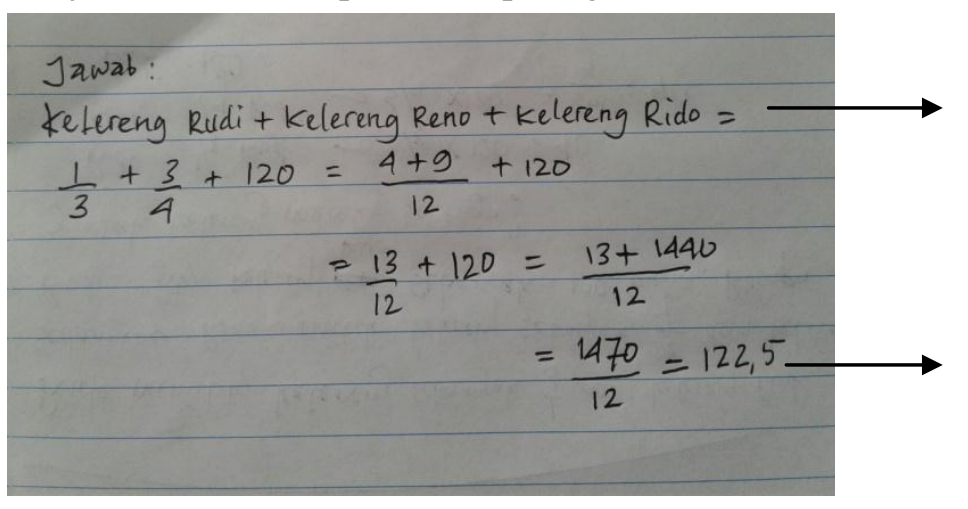

Siswa belum mampu menganalisis permintaan soal dengan langsung melakukan pemecahan masalah

Kesalahan memecahkan permasalahan yang dilakukan siswa

Gambar 1 Lembar jawaban siswa

Kairuddin. Analisis Proses Jawaban Siswa Terkait Kemampuan Pemecahan Masalah Pada Kelas Pembelajaran Kontekstual dan Kelas Pembelajaran Berbasis Masalah Pada Siswa SMP Negeri 1 Salapian. Jurnal Inspiratif. Vol. 4, No. 1 April 2018. 
Dari salah satu proses jawaban siswa di atas, terlihat bahwa kurangnya kemampuan siswa dalam mengidentifikasi masalah yang terdapat pada soal sehingga langsung melakukan proses pemecahan masalah tanpa memperhatikan terlebih dahulu informasi secara rinci. Hal ini menyebabkan siswa mengalami kesulitan untuk menentukan masalah apa yang sebenarnya harus diselesaikan. Selain itu, tahapan penyelesaian masalah yang digunakan tidak sesuai dengan prosedur penyelesaian masalah seperti yang diungkapkan oleh teori Polya yaitu mengumpulkan informasi, menentukan masalah, menyusun rencana penyelesaian, melaksanakan penyelesian dan memeriksa kembali.

Diantara model pembelajaran yang telah banyak diterapkan oleh guru di sekolah, penulis ingin meneliti lebih lanjut penerapan model pembelajaran kontekstual dan model pembelajaran berbasis masalah. Dari kedua model tersebut, peneliti ingin melihat yang mana diantara keduanya yang lebih efektif dalam meningkatkan kemampuan pemecahan masalah. Pada penelitian yang pernah dilakukan sebelumnya oleh Rusyida (2013: 6) dan Nurafiah (2013: 7), masing-masing model pembelajaran di atas mampu meningkatkan kemampuan pemecahan masalah siswa jika dibandingkan dengan pembelajaran biasa, pembelajaran langsung atau pembelajaran konvensional.

\section{METODE PENELITIAN}

\section{Jenis Penelitian}

Jenis penelitian ini berbentuk quasi eksperimenyang membandingkan dua model pembelajaran yaitu model pembelajaran kontekstual dan pembelajaran berbasis masalah dengan tujuan untuk mengetahui dan menganalisis tingkat perbedaan perlakuan terhadap kemampuan pemecahan masalah yang dimiliki siswa. Dalam tulisan ini lembar jawaban siswa dengan model pembelajaran kontekstual dan pembelajaran berbasis masalah dianalisis untuk melihat perbedaan kemampuan pemecahan masalah mereka.

\section{Tempat dan Waktu Penelitian}

Penelitian ini dilaksanakan di SMP

Negeri 1 Kecamatan Salapian Kabupaten Langkat pada kelas VII yang pelaksanaannya disesuaikan dengan jadwal kurikulum sekolah. Sampel pada penelitian ini ialah siswa kelas VII-B dengan jumlah siswa 32 orang sebagai kelas eksprimen 1 dan siswa kelas VII-C berjumlah 32 siswa sebagai kelas eksperimen 2.

\section{Validitas Soal}

Sebelum digunakan, butir soal harus telah memenuhi validitas isi dan validitas muka oleh validator. Selanjutnya, soal tes kemampuan awal matematika dan soal tes kemampuan pemecahan masalah matematika diujicoba terhadap siswa diluar kelas sampel penelitian.

\section{Analisis Jawaban Siswa}

Proses jawaban kemampuan pemecahan masalah siswa dibahas secara deskriptif. Penialian proses jawaban dilihat dari kesalahan yang diakukan siswa, kesulitan yang dihadapi, kelebihan yang dimiliki, pemenuhan indikator kemampuan pemecahan masalah dan langkah-langkah pemecahan masalah. Selanjutnya, dari analisis proses jawaban siswa tingkat kemampuan pemecahan masalah matematika siswa akan dideskripsikan berdasarkan 4 indikator kemampuan pemecahan masalah.

\section{HASIL PENELITIAN}

Langkah-langkah proses jawaban siswa terkait kemampuan pemecahan masalah pada masing-masing pembelajaran dianalisis secara deskriptif yang berkaitan dengan memahami masalah, merencanakan pemecahan masalah, menyelesaikan masalah, dan memeriksa kembali. Data yang dianalisis secara deskriptif adalah lembar jawaban siswa pada tes kemampuan pemecahan masalah untuk melihat langkahlangkah jawaban siswa yang disesuaikan dengan indikator dari kemampuan pemecahan masalah.

\section{a. Butir Soal Nomor 1}

Kairuddin. Analisis Proses Jawaban Siswa Terkait Kemampuan Pemecahan Masalah Pada Kelas Pembelajaran Kontekstual dan Kelas Pembelajaran Berbasis Masalah Pada Siswa SMP Negeri 1 Salapian. Jurnal Inspiratif. Vol. 4, No. 1 April 2018. 


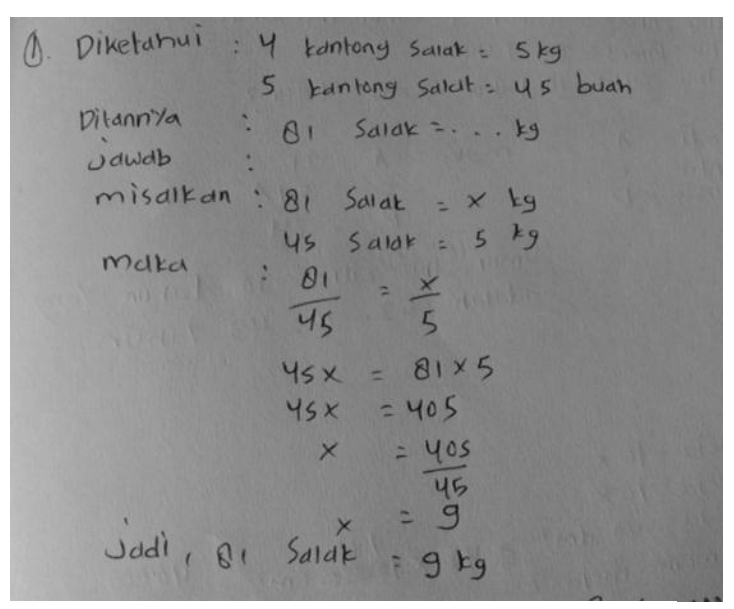

Gambar 2 (a) Jawaban Siswa Kelas Pembelajaran Kontekstual,

Gambar 2 (b) Jawaban Siswa Kelas Pembelajaran Berbasis Masalah

Pada gambar dapat kita lihat bahwa kedua proses jawaban siswa pada soal nomor 1 sudah hampir memenuhi langkahlangkah proses jawaban sesuai dengan indikator dari kemampuan pemecahan masalah. Kedua siswa tersebut telah mampu memahami masalah dengan benar, mengumpulkan informasi dari masalah dan menuliskan apa masalah sebenarnya. Keduanya juga telah mampu merencanakan penyelesaian dengan terlebih dahulu membuat permisalan dengan menggunakan " $x$ " sebagai variabel pengganti pada data

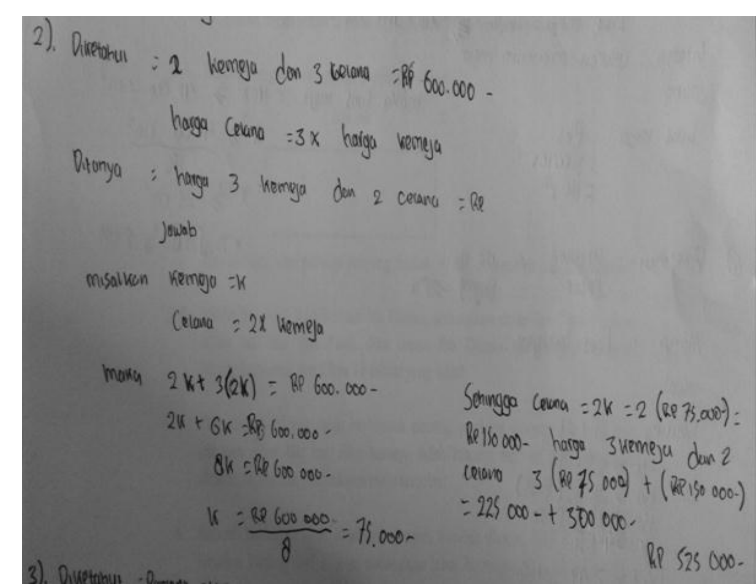

Gambar 3 (a) Jawaban Siswa Kelas Pembelajaran Kontekstual,

\section{Gambar 3 (b) Jawaban Siswa Kelas Pembelajaran Berbasis Masalah}

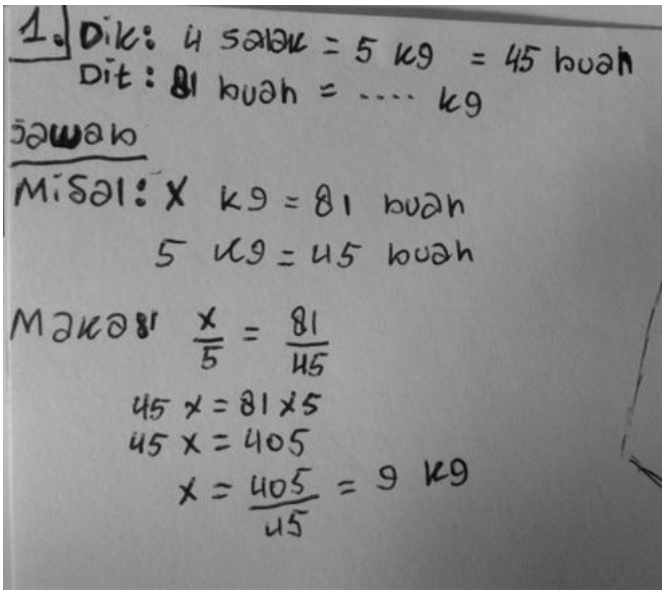

yang hilang sehingga mereka dapat menyelesaikan masalah pada butir soal tersebut. Akan tetapi mereka tidak melakukan pemeriksaan kembali dimana hal tersebut merupakan pembuktian penting dalam memperoleh hasil yang tepat.

\section{b. Butir Soal Nomor 2}

Berikut adalah Gambar 4.6 yang merupakan proses jawaban siswa kelas pembelajaran kontekstual dan siswa kelas pembelajaran berbasis masalah pada butir soal nomor 2 .

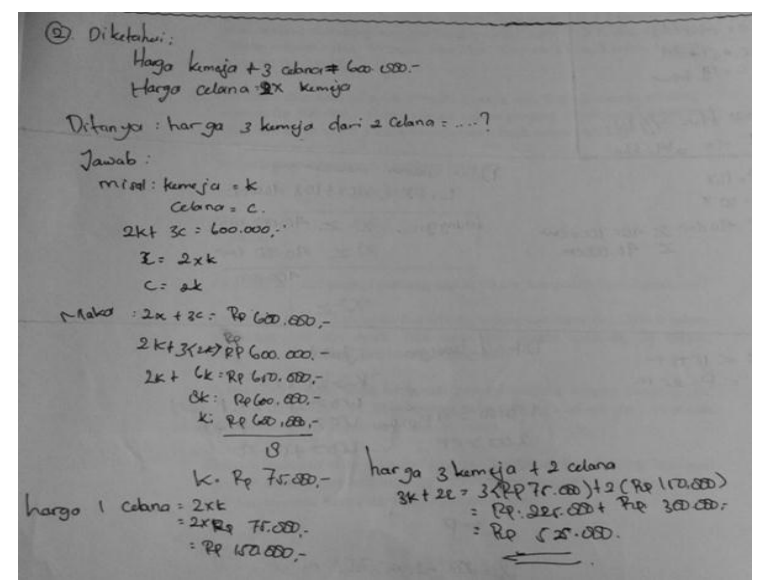

Kairuddin. Analisis Proses Jawaban Siswa Terkait Kemampuan Pemecahan Masalah Pada Kelas Pembelajaran Kontekstual dan Kelas Pembelajaran Berbasis Masalah Pada Siswa SMP Negeri 1 Salapian. Jurnal Inspiratif. Vol. 4, No. 1 April 2018. 
Pada proses jawaban butir soal nomor 2, kedua siswa pada kedua kelas pembelajaran telah memahami masalah dengan benar, merencanakan pemecahan masalah melalui permisalan dengan baik, serta memecahkan masalah dengan tepat dan benar. Terlebih lagi, kedua siswa tidak hanya memisalkan satu variabel melaikan dua variabel yaitu " $k$ " untuk variabel

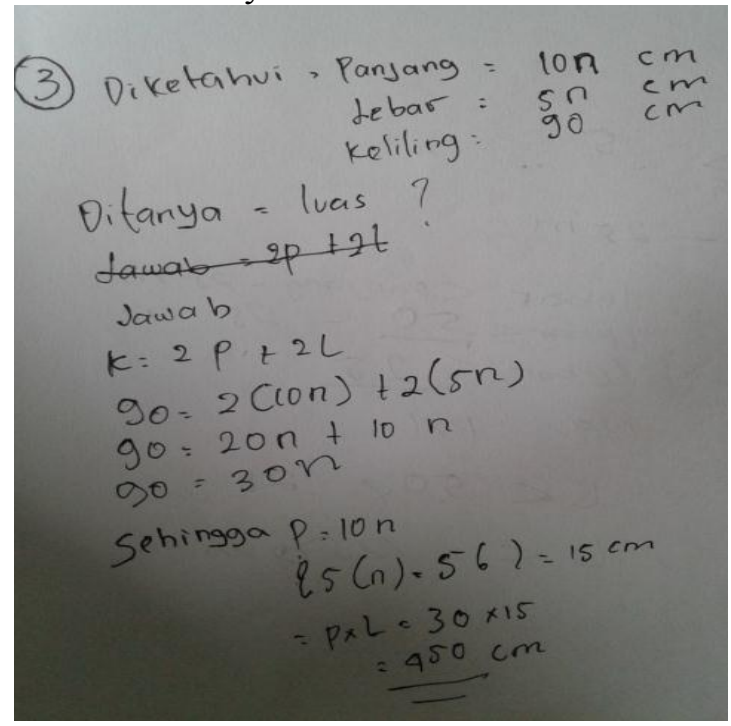

kemeja dan " $c$ " untuk variabel celana. Namun lagi-lagi kedua siswa tidak melakukan memeriksa kembali.

\section{c. Butir Soal Nomor 3}

Gambar 4 (a) dan (b) berikut ini merupakan salah satu proses jawaban siswa kelas pembelajaran kontekstual dan siswa kelas pembelajaran berbasis masalah.

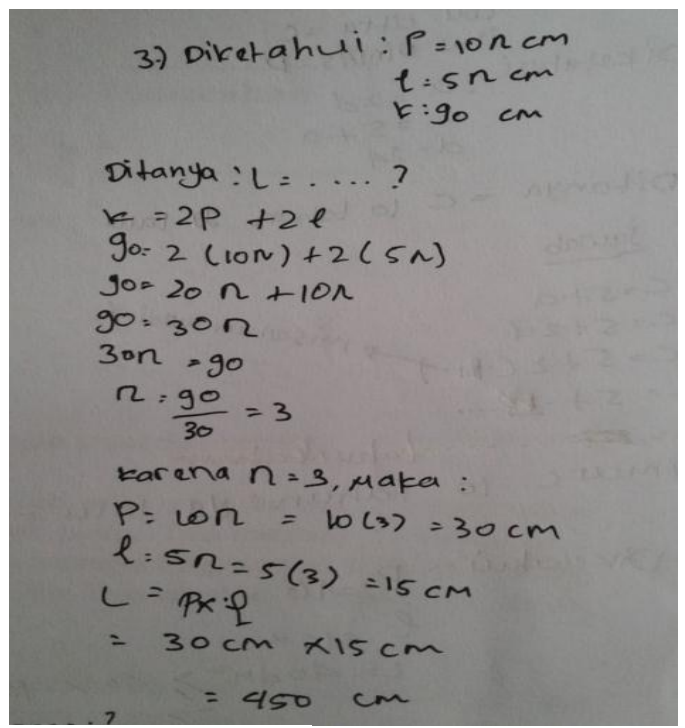

Gambar 4 (a) Jawaban Siswa Kelas

Pembelajaran Kontekstual,

\section{Gambar 4 (b) Jawaban Siswa Kelas \\ Pembelajaran Berbasis Masalah}

Kembali, kedua siswa pada butir nomor 3, baik pada kelas pebelajaran kontekstual dan kelas pembelajaran berbasis masalah melewatkan tahap memariksa kembali. Pemahaman masalah, perencanaan dan pemecahan masalah keduanya telah terpenuhi dengan baik dan benar, sehingga hasil pemecahan masalah yang diperoleh benar.

\section{d. Butir Soal Nomor 4}

Proses jawaban siswa pada butir soal nomor 4 berikut ini sama halnya dengan proses jawaban siswa pada butir soal sebelumnya, hanya terdapat perbedaan pada proses jawaban siswa kelas pembelajaran berbasis masalah, perhatikan Gambar 5 berikut.

Kairuddin. Analisis Proses Jawaban Siswa Terkait Kemampuan Pemecahan Masalah Pada Kelas Pembelajaran Kontekstual dan Kelas Pembelajaran Berbasis Masalah Pada Siswa SMP Negeri 1 Salapian. Jurnal Inspiratif. Vol. 4, No. 1 April 2018. 


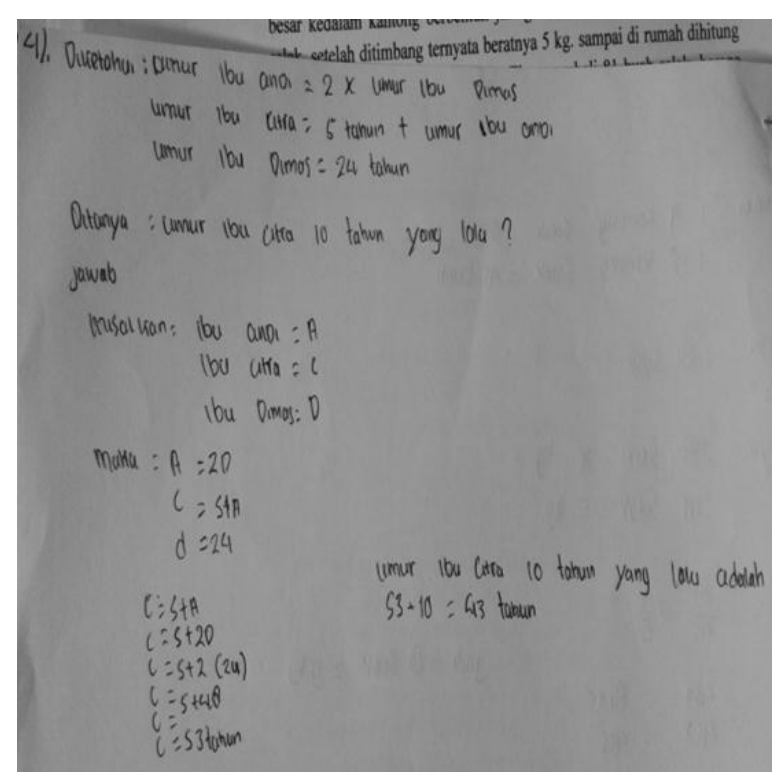

Gambar 5 (a) Jawaban Siswa Kelas Pembelajaran Kontekstual,

Pada proses jawaban siswa kelas pembelajaran kontekstual, meski tahap memeriksa kembali tetap terlewatkan, akan tetapi siswa tersebut telah memahami masalah, merencanakan pemecahan dan memecahkan masalah dengan baik dan benar. Berbeda pada siswa kelas pembelajaran berbasis masalah. Pada pemahaman dan perencanaan pemecahan masalah telah dilakukan dengan baik dan benar, akan tetapi pada pemecahan masalah siswa tersebut kurang teliti dalam

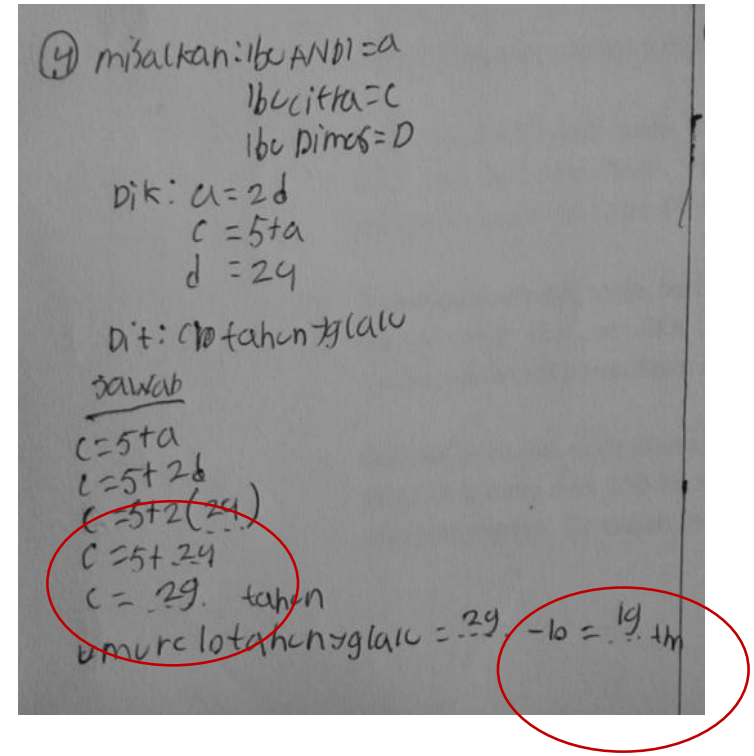

Gambar 5 (b) Jawaban Siswa Kelas Pembelajaran Berbasis Masalah

menyelesaikan proses operasi perkalian sehingga hasil yang diperoleh salah.

\section{d. Butir Soal Nomor 5}

Terdapat kesulitan yang dihadapi siswa pada butir soal nomor 5 , ini terlihat pada proses penyelesaian masalah yang dilakukan siswa, baik siswa kelas pembelajaran kontekstual maupun siswa kelas pembelajaran berbasis masalah. Perhatikan gambar 6 berikut: 


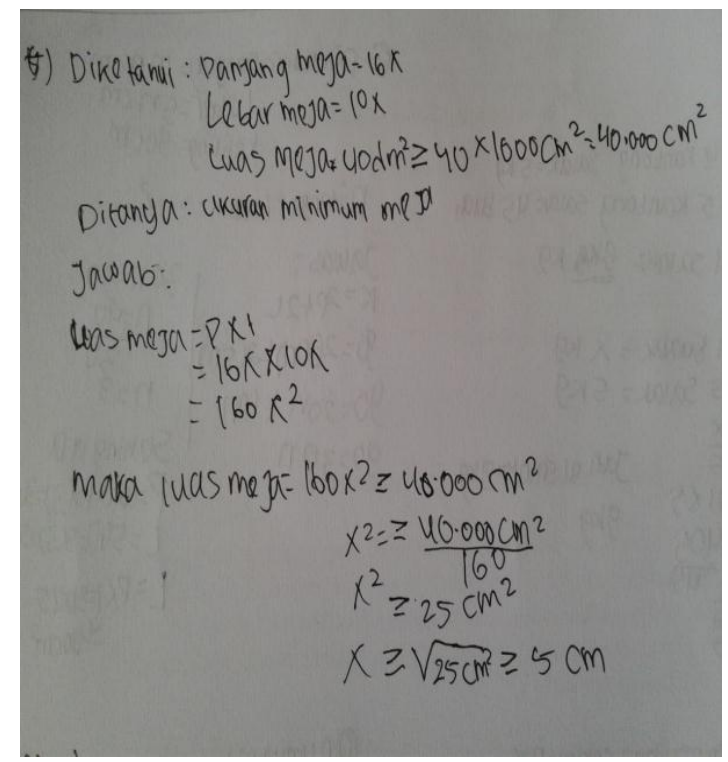

Gambar 6 (a) Jawaban Siswa Kelas Pembelajaran Kontekstual,

Awalnya kedua siswa pada masing-masing kelas terlihat memahami masalah dengan menulis segala informasi yang diketahui dan pertanyaan dari butir soal nomor 5 dengan benar. Selanjutnya pada proses perencanaan pemecahan siswa telah melakukan tahap yang benar dengan mencari luas meja terlebih dahulu menggunakan informasi yang ia peroleh. Akan tetapi pada proses pemecahan masalah siswa tidak menyelesaikan masalah tersebut, siswa terhenti pada proses perhitungan nilai akar " $x$ ". Sedangkan yang dipertanyakan adalah ukuran minimum meja. Bahkan pada siswa kelas

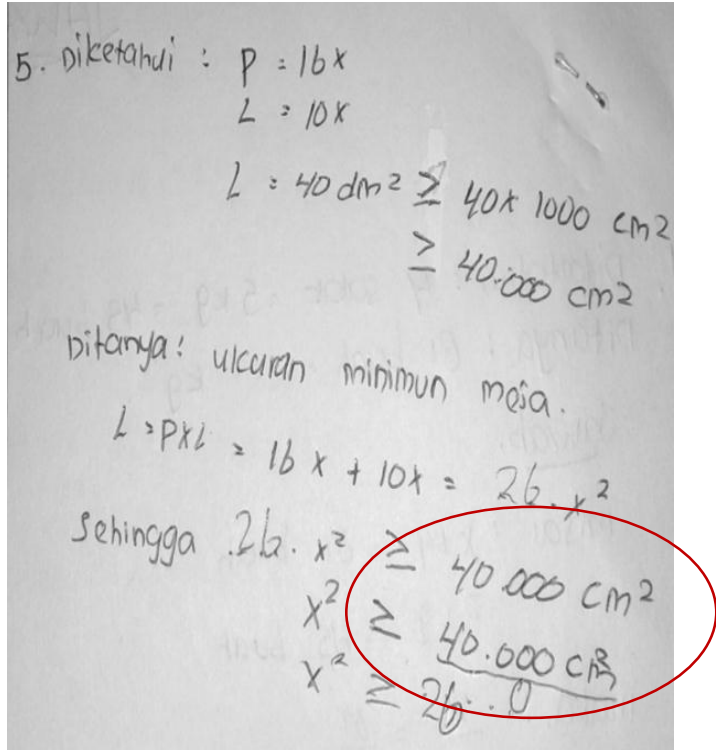

Gambar 6 (b) Jawaban Siswa Kelas Pembelajaran Berbasis Masalah

pembelajaran berbasis masalah melakukan kesalahan perhitungan nilai " $x$ ". Kesalahan ini bisa terjadi karena siswa kurang memahami permintaan soal. Padahal diawal siswa telah menuliskan apa permintaan dan solusi dari masalah tersebut.

\section{e. Butir Soal Nomor 6}

Seperti halnya butir soal nomor 5, hal yang sama juga terjadi pada butir soal nomor 6, akan tetapi kesalahan tersebut terjadi pada siswa kelas pembelajaran berbasis masalah seperti yang terlihat pada Gambar 7 (b) berikut ini: 


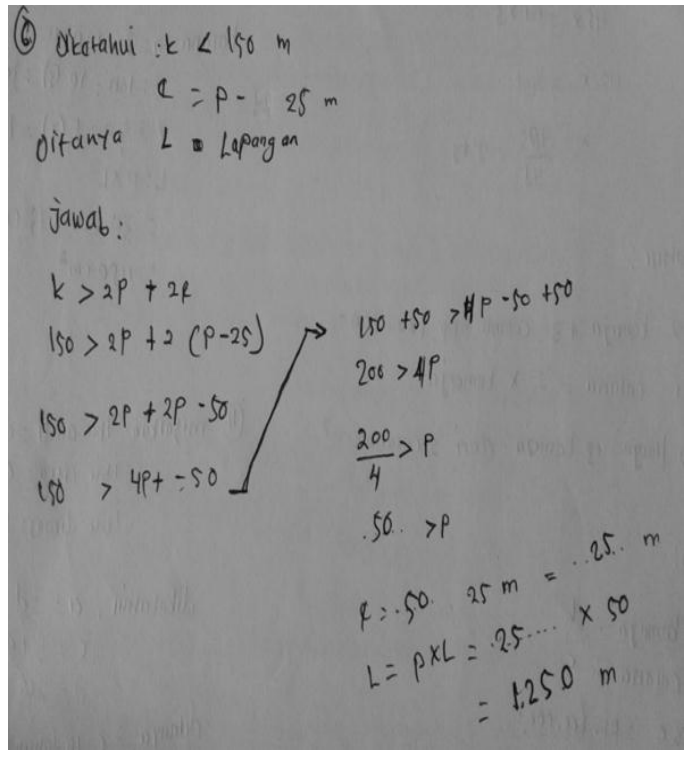

Gambar 7 (a) Jawaban Siswa Kelas Pembelajaran Kontekstual,

Pada lembar jawaban siswa kelas pembelajaran berbasis masalah terlihat siswa melakukan kesalahan pada perhitungan operasi pembagian, sehingga hasil akhir yang diperoleh dalam memecahkan masalah adalah salah.

\section{PEMBAHASAN JAWABAN SISWA}

Berdasarkan proses jawaban siswa untuk tes kemampuan pemecahan masalah dari butir soal 1 sampai dengan 6 pada masing-masing kelas pembelajaran, siswa masih menemukan kesulitan. Hal tersebut diduga karena perbedaan kemampuan masing-masing siswa dalam menyerap pengetahuan dan informasi pada setiap pembelajaran. Tetapi kesalahan yang terjadi pada siswa di masing-masing pembelajaran adalah kurangnya ketelitian terhadap pemahaman masalah dan perhitungan. Bahkan sebagian siswa masih memecahkan masalah dengan langsung memecahkan masalah dan melewatkan tahap sebelumnya.

Kebiasaan ini menjadikan proses penyelesaian masalah masih jauh dari harapan pemenuhan indikator kemampuan pemecahan masalah. Beberapa siswa menjawab dengan benar, akan tetapi tidak menuliskan informasi yang diperoleh, tidak mempersiapkan rencana pemecahan, dan juga tidak memeriksa kembali hasil

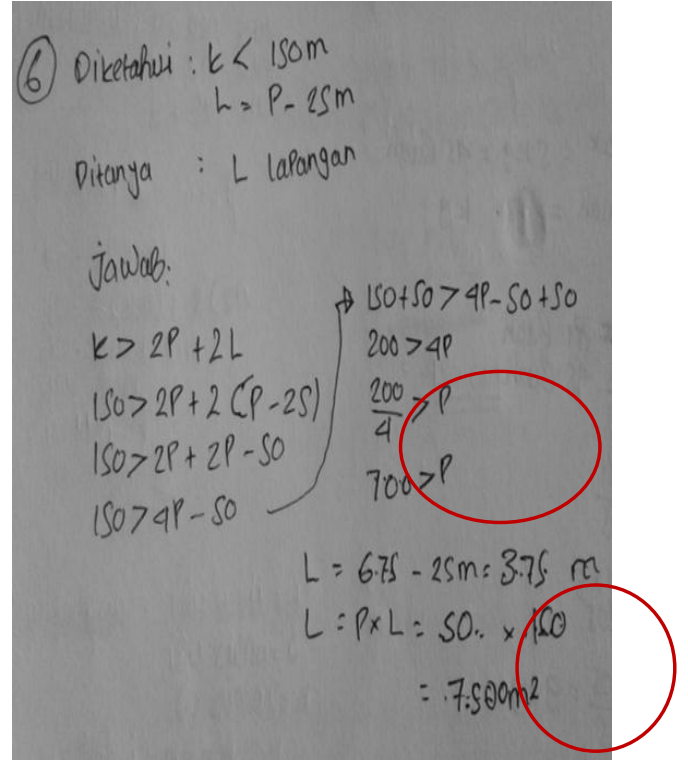

Gambar 7 (b) Jawaban Siswa Kelas Pembelajaran Berbasis Masalah

pemecahannya. Ini jelas jauh dari tahapan pemecahan masalah Polya (dalam Anggo, 2011: 37) yaitu See (memahami masalah), Plan (menyusun rencana), Do (melaksanakan rencana) dan Check (memeriksa kembali).

Untuk lebih jelas, deskripsi proses jawaban siswa dilihat berdasarkan pemenuhan indikator kemampuan pemecahan masalah matematika dapat dilihat sebagai berikut:

\section{Memahami Masalah}

Di masing-masing kelas, terdapat 6 orang siswa atau $18,75 \%$ siswa memahami masalah dengan baik yaitu menuliskan yang diketahui dengan benar tetapi tidak lengkap dan $81,25 \%$ siswa memahami masalah dengan sangat baik artinya siswa memenuhi kriteria menuliskan yang diketahui dengan benar dan lengkap.

\section{Merencakan Penyelesaian}

Dari kedua model pembelajaran predikat yang tercapai pada tingkat baik dan sangat baik. Pada kelas pembelajaran kotekstual terdapat 5 orang siswa atau $15,625 \%$ siswa merencanakan pemecahan dengan baik dan 27 orang siswa atau $84,375 \%$ siswa merencanakan pemecahan dengan sangat baik. Selanjutnya pada kelas pembelajaran berbasis masalah terdapat 10 orang siswa atau $31,25 \%$ siswa

Kairuddin. Analisis Proses Jawaban Siswa Terkait Kemampuan Pemecahan Masalah Pada Kelas Pembelajaran Kontekstual dan Kelas Pembelajaran Berbasis Masalah Pada Siswa SMP Negeri 1 Salapian. Jurnal Inspiratif. Vol. 4, No. 1 April 2018. 
merencanakan pemecahan dengan baik dan 22 orang siswa atau $68,75 \%$ siswa merencanakan pemecahan dengan sangat baik.

Pada indikator merencanakan penyelesaian, siswa dikatan baik apabila menuliskan cara yang digunakan untuk memecahkan masala dengan benar tetapi tidak lengkap dan dikatakan sangat baik apabila memenuhi kriteria menuliskan cara yang digunakan untuk memecahkan masalah dengan benar dan lengkap.

\section{Menyelesaikan Masalah}

Pada kelas pembelajaran kontekstual terdapat 8 orang siswa atau $25 \%$ siswa yang mampu menyelesiakan masalah degan predikat cukup, 18 orang siswa atau 56,25\% siswa mampu menyelesaian masalah dengan baik dan 6 orang siswa atau $18,75 \%$ siswa mampu menyelesaikan masalah dengan sangat baik. Sedangkan pada kelas pembelajaran berbasis masalah terdapat 7 orang siswa atau $21,875 \%$ siswa yang mampu menyelesiakan masalah degan predikat cukup, 20 orang siswa atau $62,25 \%$ siswa mampu menyelesaian masalah dengan baik dan 5 orang siswa atau $15,625 \%$ siswa mampu menyelesaikan masalah dengan sangat baik.

Pada indikator menyelesaikan masalah, siswa dengan predikat cukup apabila menuliskan aturan penyelesaian mendekati benar dan lengkap. Siswa menyelesaikan masalah dengan baik apabila menuliskan aturan penyelesaian dengan dengan hasil yang benar tetapi tidak lengkap. Sedangkan siswa menyelesaikan masalah dengan sangat baik apabila menuliskan aturan penyelesaian dengan hasil yang benar dan lengkap.

\section{Memeriksa Kembali}

$$
\text { Pada kelas pembelajaran }
$$

kontekstual terdapat 2 orang siswa atau $6,25 \%$ siswa yang memenuhi kritria kurang, 17 orang siswa atau $53,125 \%$ siswa memenuhi kritera cukup, 11 orang siswa atau $34,375 \%$ siswa memenuhi kriteria baik dan hanya 2 orang siswa atau 6,25\% siswa yang memenuhi kriteria sangat baik. Sedangkan pada kelas pembelajaran berbasis masah, terdpat 3 orang siswa atau
9,375\% siswa yang memenuhi kriteria kurang, 23 orang siswa atau 71,875 siswa memenuhi kriteria cukup, 5 orang siswa atau $15,625 \%$ siswa memenuhi kriteria baik dan hanya 1 orang siswa atau 3,125\% yang memenuhi kriteria sangat baik.

Kelemahan siswa pada indikator memeriksa kembali pada penelitian ini adalah kurangnya ketelitian dan kecermatan siswa dalam penyelesaian sehingga pemeriksaan yang dilakukan tidak sesuai dengan hasil penyelesaian yang menyebabkan pencapaian pada indikator ini masih kurang. Selain itu terdapat juga lembar jawaban siswa terlihat kosong pada beberapa nomor soal. Hal ini diduga karena kurangnya waktu yang digunakan dalam menyelesaikan soal. Meski demikian, lembar jawaban siswa yang kosong lebih banyak terdapat pada siswa di kelas pembelajaran berbasis masalah dibanding kelas pembelajaran kontekstual.

Berdasarkan analisa proses jawaban di atas, maka dapat dirangkum persentase proses jawaban siswa untuk butir 1 siswa kelas pembelajaran kontekstual sebanyak 29 orang siswa atau $90,625 \%$ dari 32 siswa yang memenuhi criteria menuliskan yang diketahu dengan lengkap, langkah-langkah berurutan, penyelesaian benar dan pemeriksaan dilaksanakan dengan lengkap. Sedangkan kelas pembelajaran berbasis masalah 23 orang siswa atau $71,875 \%$ dari 32 siswa yang memenuhi criteria menuliskan yang diketahu dengan lengkap, langkah-langkah berurutan, penyelesaian benar dan pemeriksaan dilaksanakan dengan lengkap. Pada butir soal nomor 2 untuk siswa kelas pembelajaran kontekstual sebanyak 22 orang siswa atau $68,75 \%$ dari 32 siswa memenuhi criteria menuliskan yang diketahu dengan lengkap, langkahlangkah berurutan, penyelesaian benar dan pemeriksaan dilaksanakan dengan lengkap. Sedangkan kelas pembelajaran berbasis masalah sebanyak 12 orang siswa atau $37,5 \%$ dari 32 siswa memenuhi kriteria menuliskan yang diketahu dengan lengkap, langkah-langkah berurutan, penyelesaian benar dan pemeriksaan dilaksanakan dengan lengkap. Selanjutnya untuk butir soal 3 untuk kelas pembelajaran kontekstual

Kairuddin. Analisis Proses Jawaban Siswa Terkait Kemampuan Pemecahan Masalah Pada Kelas Pembelajaran Kontekstual dan Kelas Pembelajaran Berbasis Masalah Pada Siswa SMP Negeri 1 Salapian. Jurnal Inspiratif. Vol. 4, No. 1 April 2018. 
terdapat 9 orang siswa atau $28,125 \%$ dari 32 siswa yang memenuhi criteria menuliskan yang diketahu dengan lengkap, langkah-langkah berurutan, penyelesaian benar dan pemeriksaan dilaksanakan dengan lengkap. Sedangkan kelas pembelajaran berbasis masalah terdapat 7 orang siswa atau $21,875 \%$ dari 32 siswa yang memenuhi criteria menuliskan yang diketahu dengan lengkap, langkah-langkah berurutan, penyelesaian benar dan pemeriksaan dilaksanakan dengan lengkap.

Untuk butir soal 4 pada kelas pembelajaran kontekstual terdapat 4 orang siswa atau $12,4 \%$ dari 32 siswa yang memenuhi criteria menuliskan yang diketahu dengan lengkap, langkah-langkah berurutan, penyelesaian benar dan pemeriksaan dilaksanakan dengan lengkap. Sedangkan pada kelas pembelajaran kontekstual terdapat 6 orang siswa atau $18,75 \%$ siswa yang memenuhi criteria menuliskan yang diketahu dengan lengkap, langkah-langkah berurutan, penyelesaian benar dan pemeriksaan dilaksanakan dengan lengkap. Jika pada butir soal sebelumnya kelas pembelajaran kontestual lebih unggul dari pada kelas pembelajaran berbasis masalah, maka pada butir soal ini kelas pembelajaran berbasis masalah lebih unggul 2 orang siswa atau 6,25\%. Lantas pada butir soal 5 banyaknya siswa yang memenuhi criteria menuliskan yang diketahu dengan lengkap, langkah-langkah berurutan, penyelesaian benar dan pemeriksaan dilaksanakan dengan lengkap pada masing-masing kelas pembelajaran adalah sama yaitu 2 orang siswa atau $6.25 \%$ dari 32 siswa. Sedangkan pada butir soal 6 tidak ada seorang siswa pun yang memenuhi criteria menuliskan yang diketahu dengan lengkap, langkah-langkah berurutan, penyelesaian benar dan pemeriksaan dilaksanakan dengan lengkap pada masing-masing pembelajaran.

\section{KESIMPULAN}

Berdasarkan analisis data dan pembahasan dalam penelitian ini, maka diperoleh kesimpulan sebagai berikut:

1. Terdapat perbedaan kemampuan pemecahan masalah matematika antara siswa yang diberi pembelajaran kontekstual dengan siswa yang diberi pembelajaran berbasis masalah dimana kemampuan pemecahan masalah siswa kelas pembelajaran kontekstual lebih baik dibanding kelas pembelajaran berbasis masalah.

2. Proses jawaban siswa pada tes kemampuan pemecahan masalah pada kelas pembelajaran kontekstual lebih baik dibanding proses jawaban siswa kelas pembelajaran berbasis masalah.

3. Respon siswa terhadap komponen dan proses pembelajaran kontekstual maupun pembelajaran berbasis masalah adalah positif.

\section{DAFTAR PUSTAKA}

Anggo, M. 2011. Pemecahan Masalah Matematika Kontekstual untuk Meningkatkan Kemampuan Metakognisi Siswa. Dalam jurnal: Edumatika, Volume 01, nomor 02. Kendari: Universitas Haluoleo.

Dahar, R.W. 2006. Teori-teori Belajar dan Pembelajaran. Jakarta: Erlangga.

Depdiknas. 2006. Peraturan Menteri Pendidikan Nasional Nomor 22 Tahun 2006 Tenntang Standar Isi Sekolah Menengah Pertama. Jakarta: Depdiknas

Nurafiah, Nurlaelah, dan Sispiyanti. 2013. Perbandingan Peningkatan Kemampuan Berpikir Kritis Siswa SMP Antara Yang Memperoleh Pembelelajaran Means-End Analysis (MEA) dan Problem Based Learning

(PBL). Dalam: Jurnal Pengajaran MIPA, Vol 18, No.1, page 1-8. Bandung: UPI.

Permendikbud. 2014. Peraturan Menteri Pendidikan dan Kebudayaan Republik Indonesia Nomor 104 Tahun 2014 Tentang Penilaian Hasil Belajar oleh Pendidik pada Pendidikan Dasar dan Pendidikan Menengah. Jakarta: Permendikbud.

Kairuddin. Analisis Proses Jawaban Siswa Terkait Kemampuan Pemecahan Masalah Pada Kelas Pembelajaran Kontekstual dan Kelas Pembelajaran Berbasis Masalah Pada Siswa SMP Negeri 1 Salapian. Jurnal Inspiratif. Vol. 4, No. 1 April 2018. 
PISA. 2011. PISA 2012 Result in Focus http://www.PISA/2012/.../.com (diakses pada Mei 2016)

Polya, G. 1985. How To Solve It, A New Aspect of Mathematical Method. USA: Princenton University Press.

Rusyida, Asikin dan Soedjoko. 2013. Komparasi Model Pembelajaran CTL dan MEA Terhadap
Kemampuan Pemecahan Masalah Materi Lingkaran. Dalam: Journal of Matehamtics Educations, vol. 2, page: 1-7. Semarang: UNNES.

TIMSS. 2011. TIMSS \& PIRL International Study Center http://www.TIMSS/2011/.../.com (diakses pada Mei 2016) 